\title{
Correlation between Tp-Te Interval and Myocardial Blush Grade Value in Anterior ST Elevation Myocardial Infarction Patient
}

\author{
Rio Probo Kaneko*, Erika Maharani, Nahar Taufiq
}

\author{
Department of Cardiology and Vascular Medicine \\ Faculty of Medicine, Public Health and Nursing Universitas Gadjah Mada - Dr. Sardjito Hospital, Yogyakarta, Indonesia \\ ${ }^{*}$ Corresponding author : \\ Rio Probo Kaneko, MD, - email: Rio.probo.k@gmail.com \\ Department of Cardiology and Vascular Medicine, Faculty of Medicine Universitas Gadjah Mada - Dr. Sardjito Hospital, \\ Yogyakarta, Indonesia, Jalan Farmako Sekip Utara, Yogyakarta 55281
}

Manuscript submitted: January 11, 2018; Revised and accepted: August 4, 2018

\begin{abstract}
Background: Clinical manifestations of coronary herat disease (CHD) may be an ST-Elevation Myocardial Infarction (STEMI). In STEMI condition, there is a metabolic disorder and ion exchange disturbance which causes dispersion of transmural repolarization, as well as micro coronary circulation disturbance involving mechanism of microvascular dysfunction. The Tp-Te interval is an electrocardiogram paramener that could be described as the transmural dispersion of repolarization. Assessment of Myocardial Blush Grade (MBG) is a coronary angiography densitometry method that can be used to assess microvascular dysfunction. This study aims to examine the correlation between Tp-Te interval and MBG in anterior STEMI.

Methods: The research desgin is cross sectional. Data were taken consecutive from August to November 2017. The Tp-Te interval assessment was performed on the basis of an electrocardiogram record from the subjects. The MBG value assessment was performed using a Quantitative Blush Evaluator (QuBE) computer program based on coronary angiography. The Tp-Te interval is divided into 2 groups: Tp-Te interval $>94 \mathrm{~ms}$ and Tp-Te interval $\leq 94 \mathrm{~ms}$. The MBG values are divided into 3 groups: MBG QUBE 1, MBG QUBE 2 and MBG QuBE 3. The assessment of Tp-Te interval and MBG value was performed by observer in intra-observer which were acknowledged based on Kappa and blindness conformity test results against patient clinical data. Pearson correlation test was used to analyze the correlation between Tp-Te interval and MBG value, while logistic regression test was used for multivariate test.

Results: Of the total 32 study subjects, there were 23 subjects with Tp-Te interval $>94 \mathrm{~ms}$ and 9 subjects with $\mathrm{Tp}-\mathrm{Te}$ interval $\leq 94 \mathrm{~ms}$. There was a negative correlationwith moderate strength between the Tp-Te interval and the MBG value in the anterior STEMI patients $(r=-0.501, p$ $=0.004$ ). There was a prevalence ratio of 4.304 between Tp-Te interval $>94$ milliseconds against MBG QuBE 1 (95\%Cl: 1.264-14.658, $p<0.001)$. Multivariate tests showed Tp-Te intervals consistently as independent risk factors for MBG values in subjects with anterior STEMI.

Conclusion: There is a negative correlation with moderate strength between the $\mathrm{Tp}-\mathrm{Te}$ interval and the MBG value in the anterior STEMI patients.
\end{abstract}

Keywords: Tp-Te Interval; myocardial blush grade; anterior STEMI

\section{INTISARI}

Latar Belakang: Penyakit Jantung Koroner (PJK) merupakan salah satu penyebab kematian terbanyak di dunia. Manifestasi PJK dapat berupa Infark Miokard Akut dengan Elevasi Segmen ST (IMA-EST) anterior. Pada IMA-EST terjadi kondisi gangguan metabolik dan gangguan pertukaran ion yang menyebabkan dispersi repolarisasi transmural, serta terjadi gangguan disfungsi mikrovaskular. Interval Tp-Te merupakan parameter elektrokardiogram yang menggambarkan dispersi repolarisasi transmural. Penilaian Myocardial Blush Grade (MBG) merupakan metode densitometrik berdasarkan hasil angiografi koroner yang dapat digunakan untuk menilai kondisi disfungsi mikrovaskular. Penelitian ini bertujuan untuk melihat hubungan interval Tp-Te dengan nilai MBG pada pasien IMA-EST anterior.

Metode: Penelitian ini menggunakan disain penelitian potong lintang. Data diambil secara prospektif dan consecutive mulai bulan Agustus hingga November 2017. Penilaian interval TpTe dilakukan berdasarkan hasil rekam EKG (elektrokardiogram) subjek penelitian. Penilaian 
MBG dilakukan menggunakan program berbasis komputer Quantitative Blush Evaluator (QuBE) berdasarkan hasil angiografi koroner subjek penelitian. Interval Tp-Te dibagi menjadi 2 kelompok yaitu interval Tp-Te $>94$ milidetik dan interval Tp-Te $\leq 94$ milidetik. Nilai MBG dibagi menjadi 3 kelompok yaitu MBG QuBE 1, MBG QuBE 2 dan MBG QuBE 3. Penilaian interval TpTe dan MBG dilakukan oleh pengamat secara intra observer yang diakui berdasarkan hasil uji kesesuaian Kappa dan buta terhadap data klinis pasien. Uji korelasi Pearson digunakan untuk meganalisis hubungan interval Tp-Te dengan nilai MBG, sedangkan uji regresi logistik digunakan untuk uji multivariat.

Hasil: Dari total 32 subjek penelitian, terdapat 23 subjek penelitian dengan interval Tp-Te $>94$ milidetik dan 9 subjek penelitian dengan interval Tp-Te $\leq 94$ milidetik. Terdapat hubungan negatif dengan kekuatan sedang antara interval Tp-Te dengan nilai MBG pada pasien IMA-EST anterior $(r=-0,501, p=0,004)$. Didapatkan rasio prevalensi sebesar 4,304 antara interval Tp-Te > 94 milidetik terhadap nilai MBG QuBE 1 (IK95\%: 1,264-14,658, $\mathrm{p}<0,001$ ). Uji multivariat menunjukan interval Tp-Te secara konsisten sebagai faktor resiko independen terhadap nilai MBG pada populasi IMA-EST anterior.

Simpulan: Terdapat hubungan negatif dengan kekuatan sedang antara interval Tp-Te dengan nilai MBG pada pasien IMA-EST anterior

\section{INTRODUCTION}

Coronary Heart Disease (CHD) is one of the leading causes of death in the world. ${ }^{1}$ Atherosclerosis is one of the most common causes of CHD. ${ }^{2}$ Clinical presentation of $\mathrm{CHD}$ may be an ST Segment Elevation Myocardial Infarction (STEMI). A STEMI condition is an emergency condition based on patomechanism of intra coronary thrombus formation. The formation of an intra coronary thrombus will cause regional perfusion disorders in the myocardium and may cause a myocardial infarction condition. $^{3}$

In STEMI condition there is a metabolic change and ion exchange disturbance. The process of change occurring at the cellular level causes a change in the repolarization period and the action potential in the infarcted myocardium. ${ }^{4}$ These repolarization differences will lead to electrophysiological heterogeneity in the myocardium and increase transmural repolarization dispersion. ${ }^{5}$

The transmural dispersion of repolarization due to myocardial infarction can be assessed through the Tpeak-Tend interval (Tp-Te interval) on the electrocardiogram (ECG). The Tp-Te interval is the time interval measured from the peak of the $T$ wave to the end of the $T$ wave on the ECG. ${ }^{6,7}$ In STEMI there is also a micro-circulatory disorder involving the process of microvascular dysfunction. Microvascular dysfunction can be assessed using both invasive and noninvasive assessments. In the invasive assessment, the assessment of microvascular dysfunction can utilize Myocardial Blush Grade (MBG) assessment that provides a direct description and evidence of microcirculation coronary and assesses the occurrence of microvascular dysfunction. ${ }^{8,9}$

Assessment of MBG can be done by qualitative and quantitative methods. The MBG assessment qualitatively uses visual observations of the intensity of contrast media in myocardium. ${ }^{10}$ Assessment of MBG quantitatively by using Quantitative Blush Evaluator (QuBE) software program that assesses the intensity of contrast media and the calculation of media area in the myocardium. ${ }^{11}$ This study aims to determine the correlation between $\mathrm{Tp}-\mathrm{Te}$ interval and MBG value in anterior STEMI patients

\section{METHODS}

This research was an observational study with cross sectional design. The subjects were anterior STEMI patients admitted in Dr. Sardjito Hospital, Yogyakarta, Indonesia who met inclusion and exclusion criteria. The inclusion criteria were: 1) adult patient age more than 18 years; 2) diagnosed STEMI anterior and performed coronary angiography in RSUP Dr. Sardjito Yogyakarta; 3) Coronary artery occlusion in the left coronary artery, both coronary artery left anterior descenden and or left circumflexa; 4) ECG recording is performed shortly before coronary angiography examination; 5) Willing to 
follow the research by agreeing to the informed consent of the study. Exclusion criteria were: 1 ) previous history of coronary heart disease; 2) Previous history of anterior STEMI; 3) Conduction block disturbance in ECG; 4) Chronic heart failure; 5) Valvular heart disease; 6) Getting medical therapy amiodarone, chloroquine, cisapride, disopyramide, erythromycin, enalapril, quinidin, verapamil and propanolol before; and 7) An ECG heart record, in the form of flat $T$ waves, artifacts or atrial fibrillation, making it difficult to assess Tp-Te intervals.

The subjects were chosen prospectively and non probability sampling in the form of consecutive sampling where subjects that meet the criteria of research subjects and have the completeness of the necessary data then included in the study. The data were taken prospectively including patient identity, patient clinical data, electrocardiogram (ECG) card recording shortly before coronary angiography examination and MBG value data obtained based on coronary angiography video. All patient data are recorded using case report form.

The recording of ECG in this study was conducted in the catheterization lab of Invasive Diagnostic and Non Heart Surgery Intervention of Dr. Sardjito Hospital, Yogyakarta just before the coronary angiography was performed on the subjects. The Fukuda Me Cardiosuny standardized ECG recording tool with standardized recording speed $25 \mathrm{~mm} / \mathrm{sec}$ and amplitude $10 \mathrm{~mm} / \mathrm{volt}$ were used. The ECG data were then collected and further scans were performed digitally.

The ECG were scanned digitally and Tp-Te interval values were measured. Measurement of $\mathrm{Tp}-\mathrm{Te}$ interval using ImageJ image ECG image analyzer program. The Tp-Te interval measurements in this study used the tail method and were carried out on V5 lead. If it can not be assessed in V5, the assessment can be made on lead V4, V6. II, III and I. The TpTe interval measurements were performed by one validated and experienced cardiologist.

Assessment of MBG value was performed based on coronary angiography results of the subjects. Assessment of MBG value was done quantitatively by using QuBE program. Coronary angiography was performed on the catheterization lab of
Invasive Diagnostic and Non Heart Surgery Intervention Dr. Sardjito Hospital, Yogyakarta using Philips Medical System angiogram equipment that has been calibrated. Assessment of MBG using Left Coronary Artery, both coronary artery Left Anterior Descenden (LAD) and or Left Circumflexa (LCx) from coronary angiography.

Coronary angiography video capture was performed at the start of a 5-10 $\mathrm{mL}$ contrast medium injection, in which the video was taken using a speed cinefilm of 12.5-25 frames per second, with RAO coronary angiography projection $20^{\circ}$ Caudal $20^{\circ}$ and using unzoom technique. Coronary angiography retrieval and recording time is performed more elongated, starting from charging contrast media in epicardial coronary artery vessels to phases where the flow of contrast media fills the coronary sinus. The coronary angiography results was analyzed by calculating the MBG value using the QuBE program by a cardiologist-interventionist consultant who had competence in MBG value assessment and have done intraobserver consistency test.

The data will be analyzed using SPSS for Windows software version 22.0. The correlation test was performed to find the correlation between $\mathrm{Tp}$-Te interval and MBG value using Pearson correlation test and multivariate analysis using logistic regression test.

\section{RESULTS}

There are 32 research subjects that met the inclusion and exclusion criteria of the study. The study period was from August 2017 to November 2017. During the study period, there were 44 subjects who met the inclusion criteria, but as many as 12 subjects were excluded because of previous history of coronary heart disease, previous STEMI history, chronic heart failure and has a picture of ECG in the form of atrial fibrillation and flat $T$ wave.

From the 32 subjects of the study, consisted of male gender as many as 27 people $(84 \%)$ and women as many as 5 people (16\%). The subjects with hypertension were 24 subjects, diabetes mellitus were 18 subjects, dyslipidemia were 13 subjects and smoker were 16 subjects. The median BMI value in this study was $25.92 \mathrm{~kg} / \mathrm{m} 2$ (19.75 - 29.75) 
and the median value of ischemic time was 6.00 (3.00-96.00) hours. In this study, there were 6 subjects who were undergone previous fibrinolysis, with successful fibrinolysis results of 5 subjects and fibrinolysis failed by 1 subject. The infarct area was found to be $\geq 4$ EKGs on 23 subjects and $\leq 3$ EKGs on 9 subjects.
The mean value of the Tp-Te interval was $107.15 \pm 19.66 \mathrm{~ms}$ and the mean value of MBG in this study was $7.84 \pm 2.94 \mathrm{AU}$. In this study, we found the involvement of coronary artery of LAD segment in 22 subjects, as well as blood vessel involvement in coronary segment of LAD and LCX in 10 subjects.

Table 1. Basic characteristics of research subjects

\begin{tabular}{|c|c|}
\hline Variables & $\begin{array}{c}\text { Value } \\
(n=32)\end{array}$ \\
\hline \multicolumn{2}{|l|}{ Gender } \\
\hline Male; $\mathrm{n}(\%)$ & 27 (84.37\%) \\
\hline Female; $\mathrm{n}(\%)$ & $5(15.63 \%)$ \\
\hline Age $\left(\right.$ Year) ${ }^{\star}$ & $60.71 \pm 10.87$ \\
\hline \multicolumn{2}{|l|}{ Risk Factor } \\
\hline Hypertension; n(\%) & $24(75.00 \%)$ \\
\hline Diabetes mellitus; $\mathrm{n}(\%)$ & $18(56.25 \%)$ \\
\hline Dyslipidemia; $n(\%)$ & $13(40.62 \%)$ \\
\hline Smoking; $n(\%)$ & $16(50.00 \%)$ \\
\hline BMI $\left(\mathrm{kg} / \mathrm{m}^{2}\right)^{* *}$ & $25.92(19.75-29.75)$ \\
\hline Ischemic time (hour) ${ }^{\star *}$ & $6.00(3.00-96.00)$ \\
\hline Fibrinolisis; $\mathrm{n}(\%)$ & $6(18.75 \%)$ \\
\hline Successful fibrinolisis & $5(83.33 \%)$ \\
\hline Failed fibrinolisis & $1(16.66 \%)$ \\
\hline \multicolumn{2}{|l|}{ Infarct size } \\
\hline$\geq 4$ ECG leads & $23(71.87 \%)$ \\
\hline$\leq 3$ ECG leads & $9(28.12 \%)$ \\
\hline Tp-Te Interval Value (ms)* & $107.15 \pm 19.66$ \\
\hline MBG value $(A U)^{*}$ & $7.84 \pm 2.94$ \\
\hline \multicolumn{2}{|l|}{ Coronary artery involvement } \\
\hline LAD; $\mathrm{n}(\%)$ & $22(68.75 \%)$ \\
\hline LCX; $n(\%)$ & $0(0 \%)$ \\
\hline LAD dan LCX; n (\%) & $10(31.25 \%)$ \\
\hline \multicolumn{2}{|l|}{ Contrast media } \\
\hline High viscosity; n(\%) & $0(0 \%)$ \\
\hline Low viscosity; $\mathrm{n}(\%)$ & $32(100 \%)$ \\
\hline
\end{tabular}

BMI: body mass index, ECG: electrocardiogram, MBG: myocardial blush grade, LAD: left anterior descenden, LCX: left circumflexa, ms: millisecond, AU: arbitrary unit

${ }^{*}$ Normal data distribution. Data shown in mean and standard deviation

${ }^{* *}$ Abnormal data distribution. Data shown in median and percentile.

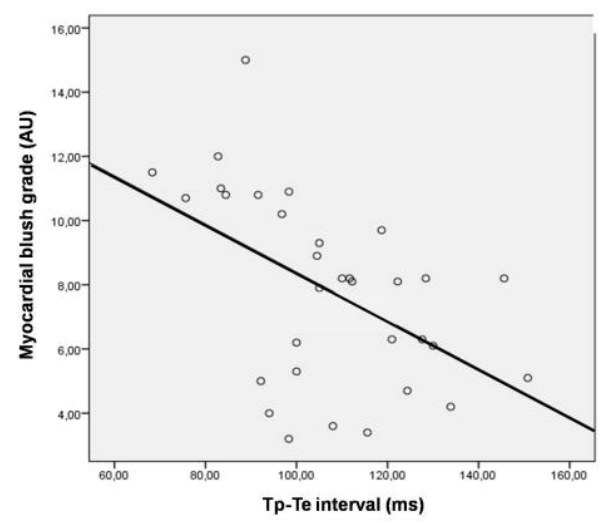

Figure 1. Scatter-plot graphic the correlation between Tp-Te interval and MBG value in anterior STEMI patients showed negative correlation with moderate strength $(r=-0.501, p=0.004)$. 
Table 2. Univariate analysis of variables that affect the Tp-Te interval on the anterior STEMI subject

\begin{tabular}{|c|c|c|c|}
\hline Variable & $\begin{array}{c}\text { Tp-Te Interval } \leq 94 \\
\text { milisecond } \\
(\mathrm{n}=9)\end{array}$ & $\begin{array}{c}\text { Tp-Te Interval > } 94 \\
\text { miliseconds } \\
(n=23)\end{array}$ & P value \\
\hline Hypertension; n(\%) & $8(88.88 \%)$ & $16(69.56 \%)$ & 0.286 \\
\hline Diabetes mellitus; $n(\%)$ & $2(22.22 \%)$ & $16(69.56 \%)$ & 0.021 \\
\hline Smoking; n(\%) & $1(11.11 \%)$ & $15(65.21 \%)$ & 0.005 \\
\hline $\mathrm{BMI} ;\left(\mathrm{kg} / \mathrm{m}^{2}\right)^{* *}$ & $27.34(21.26-29.38)$ & $25.78(19.75-29.75)$ & 0.262 \\
\hline Fibrinolytic therapy & 4 (44.44\%) & $2(8.69 \%)$ & 0.038 \\
\hline \multicolumn{4}{|l|}{ Infarct size } \\
\hline$\geq 4$ ECG leads; n(\%) & 7 (77.77\%) & $16(69.56 \%)$ & 0.501 \\
\hline$\leq 3$ ECG leads; $n(\%)$ & $2(22.22 \%)$ & $7(30.44 \%)$ & \\
\hline
\end{tabular}

BMI: body mass index, ECG: electrocardiogram

${ }^{*}$ Normal data distribution, shown in mean and standard deviation. Data were analyzed with Independent Sample T Test.

** Abnormal data distribution, shown in median and percentile. Data were analyzed with Mann Whitney Test.

Table 3. Univariate analysis of variables that affect MBG values in anterior STEMI patients

\begin{tabular}{|c|c|c|c|}
\hline Variables & $\begin{array}{c}\text { MBG } \\
\text { QuBE 1 } \\
(n=24)\end{array}$ & $\begin{array}{c}\text { MBG } \\
\text { QuBE 2 } \\
(n=8)\end{array}$ & $\begin{array}{c}\mathbf{P} \\
\text { Value }\end{array}$ \\
\hline Age (Year)* & $62.04 \pm 10.56$ & $56.75 \pm 11.53$ & 0.239 \\
\hline Hypertension; $n(\%)$ & $17(70.83 \%)$ & $7(87.50 \%)$ & 0.333 \\
\hline Diabetes mellitus; $n(\%)$ & $16(66,66 \%)$ & $2(25.00 \%)$ & 0.052 \\
\hline Dyslipidemia; n(\%) & $12(50,00 \%)$ & $1(12.50 \%)$ & 0.069 \\
\hline Smoking; $n(\%)$ & $15(62,50 \%)$ & $1(12.50 \%)$ & 0.014 \\
\hline BMl $\left(\mathrm{kg} / \mathrm{m}^{2}\right)^{\star *}$ & $27.20(19.75-29.75)$ & $25.78(21.26-29.30)$ & 0.074 \\
\hline Ischemic time (hour) $^{\star *}$ & $6.00(3.00-96.00)$ & $5.00(3.00-72.00)$ & 0.661 \\
\hline Fibrinolytic therapy & $2(8.33 \%)$ & $4(50.00 \%)$ & 0.023 \\
\hline \multicolumn{4}{|l|}{ Infarct size } \\
\hline$\geq 4$ ECG leads & $17(70.83 \%)$ & $6(75.00 \%)$ & 0.602 \\
\hline$\leq 3$ ECG leads & $7(29.16 \%)$ & $2(25.00 \%)$ & \\
\hline \multicolumn{4}{|c|}{ Coronary artery involvement } \\
\hline LAD ; n (\%) & $16(66.66 \%)$ & $6(75.00 \%)$ & 0.512 \\
\hline LCX; n (\%) & $0(0 \%)$ & $0(0 \%)$ & \\
\hline LAD and LCX ; n (\%) & $8(33.00 \%)$ & $2(25.00 \%)$ & \\
\hline
\end{tabular}

BMI: body mass index, ECG: electrocardiogram, MBG: myocardial blush grade, LAD: left anterior descenden, LCX: left circumflexa

*Normal data distribution, shown in mean and standard deviation. Data were analyzed with Independent Sample T Test.

** Abnormal data distribution, shown in median and percentile. Data were analyzed with Mann Whitney Test.

Table 4. Univariate analysis between Tp-Te interval and MBG value in the anterior STEMI patients

\begin{tabular}{|c|c|c|c|c|c|}
\hline Variabel & $\begin{array}{c}\text { MBG } \\
\text { QuBE } 1\end{array}$ & $\begin{array}{c}\text { MBG } \\
\text { QuBE } 2\end{array}$ & PR & $95 \% \mathrm{Cl}$ & $\begin{array}{c}\mathbf{P} \\
\text { Value }\end{array}$ \\
\hline Tp-Te Interval & 22 & 1 & 4.304 & $1.264-14.658$ & $<0.001$ \\
\hline Tp-Te Interval $\leq 94$ miliseconds & 2 & 7 & & & \\
\hline
\end{tabular}

MBG QuBE : Myocardial Blush Grade based on QuBE program, P: Prevalence Ratio.

Then a univariate analysis was performed between the Tp-Te interval and the MBG value and the result was shown in Table 4. 
Tabel 5. Multivariate analysis of factors affecting MBG values in anterior STEMI subjects

\begin{tabular}{|c|c|c|c|}
\hline Variables & $\begin{array}{c}\text { Prevalence } \\
\text { Ratio }\end{array}$ & $95 \% \mathrm{Cl}$ & P Value \\
\hline Tp-Te Interval & 2.471 & $1.283-12.725$ & 0.035 \\
\hline Age & 1.077 & $0.880-1.318$ & 0.298 \\
\hline Diabetes mellitus & 0.501 & $0.010-24.193$ & 0.727 \\
\hline Dyslipidemia & 0.172 & $0.002-13.332$ & 0.428 \\
\hline Smoking & 0.528 & $0.013-21.069$ & 0.734 \\
\hline Body mass index & 0.952 & $0.520-1.743$ & 0.873 \\
\hline Fibrinolytic therapy & 7.395 & $0.188-29.039$ & 0.286 \\
\hline
\end{tabular}

A correlation test was performed to assess the Tp-Te interval correlation with MBG values in anterior STEMI patients. The Tp-Te interval variable and MBG values show the distribution of normal distribution so that the correlation test is performed using Pearson test. Correlation calculation using Pearson test shows there is a negative correlation with medium strength between $\mathrm{Tp}-\mathrm{Te}$ interval with MBG value $(r=-0.501 ; p=0.004)$.

Sub analysis was performed to know about Tp-Te interval is an independent variable to $M B G$ value. $A$ univariate analysis of the Tp-Te interval group was performed, with the Tp-Te interval group divided into 2 groups, those with the Tp-Te $\leq 94$ millisecond interval and the $\mathrm{Tp}$-Te interval group $>94$ milliseconds based on the cut-off interval $\mathrm{Tp}-\mathrm{Te}$ by previous research. ${ }^{12}$ Description of the characteristics of both groups in the form of hypertension, diebetes, smoking, body mass index, previous fibrinolysis, extent of infarction and involvement of coronary artery lesions was shown in table 2.

The MBG value using the QuBE is differentiated into MBG QuBE 1 (range of QuBE values 1.3 to 10.2 arbitary units), MBG QUBE 2 (QuBE 10.2 to 15.5 arbitary units) and MBG QuBE 3 (QuBE value> 15, 6 arbitary units) based on research Vogelzang et al. (2009). Total research subjects in the MBG QuBE 1 group were 24 subjects $(75 \%)$ and MBG QuBE 2 of 8 subjects $(25 \%)$, while in this study no research subjects were included in the MBB QuBE group 3. The variables performed univariate analysis including age, hypertension, diabetes, dyslipidemia, smoking, body mass index, ischemic time, fibrinolysis, extent of infarction and coronary artery involvement were shown in table 3.
Multivariate analysis was performed on variables that could potentially be a confounding factor with a value of $p<0.25$ in univariate analysis. Multivariate analysis in this study included age, diabetes mellitus, dyslipidemia, smoking, body mass index and previous fibrinolysis (Table 5). Based on the result of multivariate analysis found that $\mathrm{Tp}-\mathrm{Te}$ interval variable was independent predictor to $M B G$ value with prevalence ratio 2.471 (95\%Cl: 1.283-12.725, $p=0.035$ ).

\section{DISCUSSION}

The variables that differed significantly between the $\mathrm{Tp}-\mathrm{Te} \leq 94 \mathrm{~ms}$ and the $\mathrm{Tp}$-Te interval $>94 \mathrm{~ms}$ groups included diabetes mellitus, smoking and previous fibrinolysis. The variables that had statistically significant differences between the MBG QuBE groups were the smoking and fibrinolysis. In this study we found 15 subjects with smoking in the MBG QuBE 1 group, compared with 1 study subjects with smoking in the MBG QuBE 2 group $(p$ $=0.014)$. This is in accordance with the previous study which showed smoking may cause a decrease in coronary microvascular function, which is associated with the inflammatory response and anatomical changes in the microvascular due to various substances within tobacco. ${ }^{13}$ In the MBG QuBE 1 group, there were only 2 subjects who underwent fibrinolysis, while in the MBG QuBE 2 group, 4 subjects were subjected to fibrinolysis $(p=0.023)$. In IMAEST patients, fibrinolysis may improve myocardial condition by a decreased in the area of infarction in the myocardium. . $^{4,15}$

In the correlation test between the Tp-Te interval and the MBG value using the Pearson correlation test, there was a moderate-strength negative correlation between the Tp-Te interval and the MBG value $(r=-0.501, p=0.004)$. It shows the 
longer Tp-Te interval the lower the MBG value. Acute myocardial infarction causes changes in action potential through interference of intracellulare $\mathrm{K}^{+}, \mathrm{Na}^{+}$and intra-cellular $\mathrm{Ca}_{2}{ }^{+}$ions. The ion exchange disturbance will cause a change in the heterogeneity of myocardial repolarization, which increases the repolarization difference between epicardium cells, endocardium and myocardium $M$ cells. Such increased repolarization will lead to an increase in the dispersion of myocardial transmural repolarization. The transmural repolarization dispersion can be represented in the ECG record of the Tp-Te interval increasingly elongated. ${ }^{16}$ This is in accordance with previous research that showed an extension of Tp-Te interval in STEMI patients compared with healthy control group. ${ }^{16}$ Another study showing an increased dispersion of transmural repolarization in STEMI patients indicated by prolonged $\mathrm{Tp}-\mathrm{Te}$ interval which shown a significant elongated Tp-Te interval (114 \pm $3.1 \mathrm{~ms}$ ) in the STEMI group compared to the control group. ${ }^{17}$

In STEMI, microvascular dysfunction may occur. The microvascular dysfunction occurs through several mechanisms such as microvascular damage associated with ischemia, distal embolization and individual susceptibility factors. ${ }^{18}$ Assessment of MBG is one of the evaluation methods for assessing microvascular circulation. Assessment of MBG provides a direct description of coronary microvascular perfusion. ${ }^{9}$ The MBG assessment can be used to assess visual microvascular filling and be a marker of the occurring microvascular dysfunction. ${ }^{19}$ The quantitative MBG assessment using the QuBE program has a significant correlation with qualitative MBG degrees. ${ }^{11}$ Increased QuBE values are associated with decreasing MBG degrees. ${ }^{11}$

In this study, the factors of age, diabetes mellitus, dyslipidemia, smoking, body mass index and previous fibrinolysis were calculated as confounding factors of $\mathrm{Tp}-\mathrm{Te}$ interval and MBG value. Acute hyperglycaemia and diabetes mellitus did not affect the vasodilatory response of the coronary microcirculatory, thus causing no coronary artery micro-disturbance and microvascular dysfunction. ${ }^{20} \mathrm{An}$ increase in $\mathrm{BMI}>30$ and obesity are associated with a decrease in coronary microvascular density, which contributes to microvascular dysfunction, decreased myocardial blood flow, myocardial metabolic disorders, diastolic dysfunction and increased risk of heart failure. ${ }^{21}$ Smoking can also cause a decrease in coronary blood flow through decreased rates of hyperemic coronary blood flow. ${ }^{22}$ Research by Mikelsone et al. (2011) showed that in the group of adult patients who smoked chronically with mean duration of smoking $>20$ years associated with higher degree of microvascular dysfunction. ${ }^{13}$ The fibrinolysis is the administration of a medical agent to lyse or dissolve blood clots that acutely obstruct the coronary arteries in the STEMI, thus providing an improvement in myocardia. Its improvement decreased myocardial and microcirculation disturbance and improved microvascular dysfunction.

In this study there is a limited time research, so the number of research subjects recruited in this study has not met the number of subjects according to the calculation of estimated number research subjects. Another limitation of this study is the coronary angiography performed for MBG assessment, contrast media injection in this study has not used contrast media injector tool, performed manually, due to unavailability of contrast media injector device in coronary vein, so the pressure and speed of injection contrast media at the time of coronary angiography does not meet the standard.

\section{CONCLUSION}

There was a negative correlation with moderate strength between the Tp-Te interval and the MBG value in the anterior STEMI patients and the Tp-Te interval was an independent variable against the MBG value.

\section{REFERENCES}

1. Widimsky P., Wijns W., Fajadet J., De Belder M., Knot J., Aaberge L. 2010. Reperfusion therapy for ST elevation acute myocardial infarction in Europe: description of the current situation in 30 countries. Eur Heart J, 31:943-957.

2. Naghavi M., Libby P., Falk E., Casscells S.W., Litovsky S., Rumberger J., et al. 2003. From vulnerable plaque to vulnerable patient : a call for new definitions and risk assesment strategies. Circulation, 108: 1664-1672.

3. June W.R., Sabatine M.S., Lilly L.S. 2011. Patophysiology of heart disease: 
Ischemic Heart Disease. Lippincott Williams and Wilkins

4. Burton F.L., Cobbe, S.M. 2001. Dispersion of ventricular repolarization and refractory period. Cardiovasc Res, 50:10-23.

5. Carmeliet E. 1999. Cardiac ionic currents and acute ischemia : From channels to arrythmias. Physiol Rev, 79:917-1017.

6. Antzelevitch C., Viskin S., Shimizu W., Yan G.X., Kowey P., Zhang L., et al. 2007. Does Tpeak - Tend provide an index of transmural dispersion of repolarization? Heart Rhythm, 4:11141119.

7. Jiang X., Zhao H., Ji Z., Liu G., Liu L. 2013. The correlation of $t$ peak-t end interval and ventricular arrhythmia in patients with acute myocardial infarction. Tianjin Med J, 41:740-743.

8. Chesebro J.H., Knatterud G., Roberts R., Borer J., Cohen L.S., Dalen J., et al. 1987. Thrombolysis in Myocardial Infarction (TIMI) Trial, Phase I: A comparison between intravenous tissue plasminogen activator and intravenous streptokinase. Clinical findings through hospital discharge. Circulation, 76:142154.

9. van 't Hof A.W., Liem A., Suryapranata H., Hoorntje J.C., de Boer M.J., Zijlstra F.1997. Angiographic assessment of myocardial reperfusion in patients treated with primary angioplasty for acute myocardial infarction : myocardial blush grade. Zwolle myocardial infarction study group. Circulation, 97:2302-6.

10. Gibson C.M., Schomig, A. 2004. Coronary and myocardial angiography: angiographic assessment of both epicardial and myocardial perfusion. Circulation, 109:3096-3105.

11. Vogelzang M., Vlaar P.J., Svilaas T., Amo D., Nijsten, M.W., Zijlstra,F. 2009. Computer assisted myocardial blush quantification after percutaneous coronary angioplasty for acute myocardial infarction: A substudy from the TAPAS trial. Eur Heart $\mathrm{J}$. 30:594-599

12. Haarmark C., Graff C., Andersen M.P., Hardahl T., Struijk J.J., Toft E., et al. 2010. Reference value of electrocardiogram repolarization variables in a healthy population. $\mathrm{J}$ Electrocardiol, 43:31-39.
13. Mikelsone I., Bormane I., Simsone Z., Jurka A., Tretjakovs P. 2011. The effect of chronic cigarette smoking on microvascular function, insulin resistance and inflamatory state. Environ and Exp Biology, 9:23-28.

14. Melandri G., Branzi A., Semprini F., Cervi V., Galie N., Magnani B. 1990. Enhanced thrombolytic efficacy and reduction of infarct size by infusion of streptokinase and heparin. $\mathrm{Br}$ Heart $\mathrm{J}$, 64:118-120.

15. Morrison L.J., Verbeek P.R., McDonald A.C., Sawadsky B.V., Cook D.J. 2000. Mortality and pre hospital thrombolysis for acute myocardial infarction; A-meta analysis. JAMA, 283:2686-2692.

16. Shentar J., Deora S., Rai M., Nanjappa M.C. 2015. Prolonged t peak-end and $t$ peak end/qt ratio as perdictors of malignant ventricular arrythmias in the acute phase of st segment elevation myocardial infarction : a prospective case-control study. Heart Rhythm, 12:484-489.

17. Gupta P., Patel C., Narayanaswamy S., Malhotra B., Green J.T, Yang G.X. 2008.Tp-e/QT ratio as an index of arrythmogenesis. J Electrocardiol, 41:567-574.

18. Niccoli G., Scalone G., Lerman A., Crea F. 2016. Coronary microvascular obstruction in acute myocardial infarction. Circulation, 37:1024-1033.

19. Porto I., Hamilton-Craig C., Brancati M., Burzotta F., Galiuto L. 2010. Angiographic assesment of microvascular perfusion - Myocardial blush in clinical practice. Am Heart $\mathrm{J}$, 160:1015-1022.

20. Capaldo B., Galderisi M., Turco A.A., D'errico A., Turco S., Rivellse A.A., et al. 2005. Hyperglycemia does not affect the reactivity of coronary microcirculation in humans. J Clin Endocrinol Metab. 90:3871-3876.

21. Campbell D.J., Somaratne J.B., Prior D.L., Kenny J.F., Newcomb A.E., Kelly D.J. 2013. Obesity is associated with lower coronary microvascular density. Ann Intern Med, 1:e8179-e8198.

22. Gullu H., Caliskan M., Ciftci O., Erdogan D., Topcu S., Yildirim E., et al. 2006. Light cigarette smoking impairs coronary microvascular functions as severely as smoking regular cigarettes. Heart, 93:1274-1277. 